\title{
Perkembangan Minat Masyarakat pada Madrasah Aliyah di Kota Gorontalo
}

\author{
Buhari Luneto \\ IAIN Sultan Amai Gorontalo \\ Email: buhariluneto@yahoo.com
}

\begin{abstract}
The Act No. 20, 2003 of National Education System explains that Madrasah Aliyah as an Islamic educational institution has been equated with other public schools. This equivalence does not change automatically the public of Gorontalo perception toward Madrasah Aliyah as a second choice. Such perception affects the community interest to send their children to Madrasah Aliyah. However, Madrasah Aliyah in Gorontalo still has great prospect in the future. So some very urgent improvement and imaging is performed by Madrasah Aliyah. This improvement is very important because most people see Madrasah Aliyah as second-class school and its graduates do not have brilliant future. In fact, Madrasah Aliyah can create human resources who have intact insight, are divinity insight, social insight and scientific insight.
\end{abstract}

Keywords: social interest, noble ethics, social goodness

\begin{abstract}
Abstrak
Madrasah Aliyah sebagai sebuah lembaga pendidikan Islam telah disetarakan kedudukannya dengan sekolah umum lainnya berdasarkan UU No. 20 tentang Sistem Pendidikan Nasional RI Tahun 2003.Meski posisinya setara, tidak serta merta merubah persepsi masyarakat Gorontalo terhadap Madrasah Aliyah sebagai pilihan kedua. Persepsi seperti ini mempengaruhi minat masyarakat untuk menyekolahkan anak-anaknya ke Madrasah Aliyah. Meski demikian, Madrasah Aliyah di Gorontalo masih memiliki prospek yang besar di masa depan. Maka beberapa terobosan yang sangat urgen dilaksanakan adalah pembenahan dan pencitraan terhadap Madrasah Aliyah. Ini penting karena sebagian besar masyarakat memandang Madrasah Aliyah sebagai sekolah kelas dua serta lulusan Madrasah Aliyah yang tidak memiliki jaminan masa depan yang cemerlang. Padahal, Madrasah Aliyah dapat menciptakan sumber daya manusia yang memiliki wawasan yang utuh yaitu wawasan ketuhanan, wawasan kemasyarakatan dan wawasan keilmuan.
\end{abstract}

Kata kunci: minat masyarakat, akhlak mulia, kesalehan sosial. 


\section{A. Pendahuluan}

Pengembangan pendidikan Islam ke depan secara realistis harus disinkronisasikan dengan kebijakan pendidikan nasional guna membebaskan bangsa dari himpitan berbagai persoalan. Sejak terbitnya Undang Undang Nomor 2 Tahun 1989 tentang Sistem Pendidikan Nasional yang dijabarkan lebih lanjut dengan peraturan pemerintah No. 29 Tahun 1990 telah menempatkan posisi pendidikan madrasah sama dengan pendidikan umum, baik dari segi kurikulum, guru, mutu lulusan, ijazah, unit cost maupun sarana prasarana pendidikan.

Dengan demikian tidak ada lagi dualisme sistem pendidikan di Indonesia karena baik sekolah umum maupun madrasah adalah pelaksana sistem pendidikan nasional dan pelaksana wajib belajar 9 tahun yang merupakan program nasional. Demikian pula dalam Undang-Undang Sistem Pendidikan Nasional Nomor 20 Tahun 2003 menempatkan madrasah sejajar dengan sekolah umum dan menjadi satu sistem pendidikan nasional yang merupakan keseluruhan komponen pendidikan yang saling terkait secara terpadu untuk mencapai tujuan pendidikan nasional.

Agar lembaga-lembaga pendidikan Islam tetap bertahan dan mampu merespons kebutuhan masyarakat pada setiap zaman, maka ia harus memiliki strategi peningkatan kualitas dan cara pengukuran yang efektif. Strategi tersebut pada dasarnya bertumpu pada kemampuan memperbaiki dan merumuskan visinya setiap zaman yang dituangkan dalam rumusan tujuan pendidikan yang jelas. Jika pemerintah sekarang telah mendorong pendirian sekolah unggulan (competitive education institution) di setiap kabupaten, yang berupa SMU unggulan, maka perlu pula dipikirkan untuk mendirikan Madrasah Aliyah unggulan. Semakin banyak sekolah bermutu di daerah maka sudah barang tentu akan menguntungkan masyarakat. Untuk mencapai lembaga pendidikan Islam yang berkualitas, pengembangan sarana prasarana institusi pendidikan Islam adalah suatu keharusan. Pengembangan tersebut mencakup kurikulum, kualitas pendidik, proses pembelajaran yang demokratis, penumbuhan daya kritis anak didik, dan lain-lain. Pengembangan aspek-aspek tersebut sudah tentu membutuhkan peningkatan anggaran pendidikan. ${ }^{1}$

\footnotetext{
${ }^{1}$ Abdullah Idi dan Toto Suharto, Revitalisasi Pendidikan Islam, (Yogyakarta: Tiara Wacana, 2006), hlm. 141.
} 
Kendati peluang lembaga pendidikan Islam untuk eksis di era yang kompetitif ini semakin terbuka, namun pada tingkat realitas masa kini, khususnya di Provinsi Gorontalo, lembaga pendidikan Islam belum menjadi main goal (sasaran utama) apalagi menjadi primadona pendidikan. Dihubungkan dengan tiga unggulan program pemerintah provinsi Gorontalo, lembaga pendidikan Islam sesungguhnya mesti mengambil peran yang jelas. Sebab salah satu program unggulan itu adalah pengembangan dan peningkatan Sumber Daya Manusia. ${ }^{2}$

Hal yang perlu dicermati bahwa di Provinsi Gorontalo misalnya, jumlah Madrasah Aliyah Negeri 3 buah dan Swasta 17 buah, belum sebanding dengan jumlah SMU/SMK Negeri 15 buah dan Swasta 25 buah. Pada tingkat lembaga pendidikan tinggi, di Provinsi Gorontalo terdapat 6 Perguruan Tinggi, sedangkan Perguruan Tinggi Islam hanya ada 1 buah (IAIN Sultan Amai Gorontalo) plus Universitas Muhammadiyah Gorontalo yang pada tahun akademik 2008/2009 untuk pertama kalinya memulai kegiatan akademik. Demikian pula dengan jumlah siswa-mahasiswa yang perbandingannya tidak proporsional. Bahkan berdasarkan hasil survei sementara bahwa ada beberapa lembaga pendidikan Islam hampir tidak memperoleh siswa pada tahun ajaran 2004/2005. Fenomena ini justru berbanding terbalik dengan jumlah penduduk Gorontalo yang mayoritas beragama Islam ( $\pm 95 \%)$. Hal ini menunjukan rendahnya minat masyarakat Gorontalo terhadap lembaga pendidikan Islam.

\section{B. Perkembangan Madrasah Aliyah di Kota Gorontalo}

Posisi kota Gorontalo sebagai pusat pemerintahan Provinsi Gorontalo menjadikan kota Gorontalo menjadi tujuan para siswa untuk bersekolah. Enam Madrasah Aliyah di kota Gorontalo menyebar di beberapa tempat/kecamatan yaitu MAN Model Gorontalo berada di Kota Utara tidak jauh dari lokasi MA Nurul Yaqiin yang belum lama didirikan. Di Kota Barat terdapat MA al-Yusra, di Kota Timur terdapat MA al-Khairaat dan di Kota Selatan berdiri MA al-Huda dan di Kota Tengah terdapat MA Muhammadiyah Gorontalo. Posisinya yang menyebar memungkinkan keenam

${ }^{2}$ Dua program unggulan Provinsi Gorontalo lainnya adalah program pengembangan pertanian dan etalase perikanan. 
Madrasah Aliyah menampung siswa dari berbagai arah, baik dari kota Gorontalo maupun dari luar kota Gorontalo.

Keenam Madrasah Aliyah di kota Gorontalo berpencar di beberapa titik, yakni 2 di pusat kota, dan 4 di daerah pinggiran kota yang memudahkan bagi siswa dari kabupaten lain mengakses madrasah. Dua madrasah yang berada di pusat kota adalah Madrasah Aliyah al-Huda dan Madrasah Aliyah Muhammadiyah, kedua madrasah ini tidak berdekatan. Jarak dari Madrasah Aliyah al-Huda ke Madrasah Aliyah Muhammadiyah sekitar $1 \mathrm{~km}$. AlHuda berada di sebelah selatan, berada dekat dengan pusat perdagangan, sementara Madrasah Aliyah Muhammadiyah berada di sebelah timur pasar Sentral Gorontalo, tak jauh dari kampus I IAIN Sultan Amai Gorontalo. Posisi keduanya yang berada di tengah kota menjadi alasan kenapa lebih banyak siswanya berasal dari kota Gorontalo.

Sementara itu, MAN Model berada di Kota Utara Jl. Poigar berhampiran dengan kantor wilayah Kementerian Agama RI. Berada di sebelah utara kota Gorontalo. Jarak MAN dengan pusat kota sekitar $5 \mathrm{~km}$. dari MAN Model ke arah timur sekitar $3 \mathrm{~km}$ adalah Madrasah Aliyah al-Yusra, berada di perbatasan kota Gorontalo dengan kecamatan Telaga Kabupaten Gorontalo, persisnya di Jl. Beringin Kelurahan Tomulabutao Dungingi. Sedangkan Madrasah Aliyah al-Khairaat dari pusat Kota sekitar $3 \mathrm{~km}$ ke arah timur,berada di kelurahan Dembe II Kota Timur yang berbatasan dengan kabupaten Bone Bolango. Yang terakhir adalah Madrasah Aliyah Nurul Yaqiin. Madrasah ini tak jauh dari MAN Model Gorontalo, berjarak sekitar $4 \mathrm{~km}$ ke arah timur.

Posisi Madrasah Aliyah yang berpencar seolah membentengi daerah kota Gorontalo dari berbagai penjuru. Posisi ini berbeda dengan sekolah umum yang berdekat-dekatan satu sama lain dan cenderung dekat dengan pusat kota. Berikut ini akan dipaparkan perkembangan enam Madrasah Aliyah di kota Gorontalo.

1. Madrasah Aliyah Negeri Model Gorontalo ${ }^{3}$

Madrasah Aliyah Negeri (MAN) Model Gorontalo adalah alih fungsi pendidikan Guru Agama Negeri (PGAN), salah satu

${ }^{3}$ Data dan informasi diperoleh dari Profil Madrasah MAN Model Gorontalo 2010 . 
dari 90 buah PGAN. Yang terbesar di seluruh Indonesia berdasarkan SK MenteriAgama RI No. 64 Tahun 1990 tertanggal 25 April 1990.

Setelah beralih status dari PGAN Gorontalo menjadi MAN Gorontalo, maka dalam kurun waktu 12 tahun yakni dari tahun pelajaran 1990/1991 sampai tahun pelajaran 2002/2003, kembali mengukir sejarah perkembangannya menjadi MAN Model Gorontalo yang Ke-37 dari 38 MAN Model di seluruh Indonesia. Perubahan Status ini karena terbentuknya Provinsi Gorontalo yang terpisah dari Provinsi Sulawesi Utara. Di bawah kepemimpinan Gubernur Provinsi Gorontalo DR. Ir. H. Fadel Muhammad, berdirilah Kantor Wilayah Departemen Agama provinsi Gorontalo di bawah kepemimpinan Drs. H. Mohammad Salim Aldjufri, M.Sos berdasarkan SK Direktur Jenderal Kelembagaan Agama Islam Departemen Agama No. DJ.II/15/03, tertanggal 10 Maret 2003. Peresmian MAN Model Gorontalo dilaksanakan pada tanggal 22 Mei 2003 oleh Dr. H. A. Qodri A. Azizy, MA selaku Direktur Jenderal Kelembagaan Agama Islam Departemen Agama RI.

Perkembangan dan tantangan masa depan seperti: perkembangan ilmu pengetahuan dan teknologi, globalisasi yang sangat cepat, era informasi, dan berubahnya kesadaran masyarakat dan orang tua terhadap pendidikan memicu madrasah untuk merespons tantangan sekaligus peluang itu. MAN Model Gorontalo memiliki citra moral yang menggambarkan profil madrasah yang diinginkan di masa datang yang diwujudkan dalam visi madrasah adalah Dinamis, Berimtaq, Edukatif, Santun \& Terampil. Visi tersebut di atas mencerminkan citacita madrasah yang berorientasi ke depan dengan memperhatikan potensi kekinian, sesuai dengan norma dan harapan masyarakat.

Tanah madrasah sepenuhnya milik negara. Luas area seluruhnya $2680 \mathrm{~m}^{2}$. Sekitar madrasah dikelilingi oleh pagar setinggi 2 meter. Bangunan madrasah pada umumnya dalam kondisi baik. Yakni terdapat 25 Jumlah ruang kelas serta 35 ruangan bukan kelas untuk menunjang kegiatan belajar memadai dengan Luas Bangunan: $2.736 \mathrm{~m}^{2}$. Sementara pendanaan madrasah ini berasal dari dana pemerintah dan dana yang dihimpun dari orang tua peserta didik. Setiap peserta didik dikenai biaya Rp. 50.000,- per bulan. 
MAN Model Gorontalo didirikan pada tahun 1961 dengan pimpinan madrasah yang pernah bertugas di MAN Model Gorontalo sejak awal berdirinya hingga Sekarang telah 9 kali mengalami pergantian kepemimpinan masing-masing: Mohamad Podungge (1964-1972), Drs. KH. Hamrain Kau (19731978), Abdullah Sidiki, (1979-1989), Drs. Abd. Jabar Dale (1990-1993), Ahmad Ishak, (1994-1995), Rusdiyanto Podungge, (1995-1999), Drs. Adam Tadu, M.Pd.I (1999-2006), Drs. Tahar Kurhas, M.Pd.I (2006), Syafrudin Baderung, M.Pd (2007-sekarang).

Jumlah seluruh tenaga kependidikan madrasah sebanyak 69 orang, terdiri atas guru 59 orang, karyawan tata usaha 7 orang, Satpam 2 orang dan Cleaning Service 3 orang. Dari kualifikasi pendidikan, para guru di madrasah ini sebagian besar adalah sarjana, dan beberapa telah bergelar magister, masing-masing 5 orang guru magister (S2), selebihnya 54 orang bergelar sarjana (S1) baik dari perguruan tinggi Islam maupun umum.

Sementara itu, jumlah peserta didik pada tahun pelajaran 2010/2011 seluruhnya berjumlah 531 orang. Peserta didik di kelas X ada sebanyak 6 rombongan belajar. Peserta didik pada kelas XI terdapat 9 rombongan belajar dan di kelas XII terdapat 7 rombongan belajar. Secara rinci siswa kelas X sebanyak 202 orang, siswa kelas XI sebanyak 143 orang dan siswa kelas XII sebanyak 186 orang.

Latar belakang siswa berdasarkan data peserta Ujian Nasional 2011, hanya sebagian kecil siswa yang berasal dari kota Gorontalo yaitu sebanyak 58 siswa, sementara dari luar kota Gorontalo sebanyak 68 orang dan dari luar daerah sebanyak 60 orang, di mana sebagian besar berasal dari Bolaang Mongondow Sulawesi Utara. Dilihat dari latar belakang ekonomi, sebagian besar siswa berasal dari keluarga kurang mampu. Data pekerjaan orang tua siswa menunjukkan bahwa 72 orang petani, 12 orang nelayan, 11 orang buruh, sopir angkot 2 orang, tukang 9 orang, dagang 44 orang, pekerja tambang 1 orang dan hanya 24 yang berstatus pegawai negeri sipil, baik sebagai guru, kepala kelurahan dan polisi. Data ini menunjukkan bahwa hanya sebagian kecil siswa berasal dari keluarga kelas menengah. Tidak ditemukan siswa dengan latar belakang orang tua sebagai pejabat atau pengusaha. 
2. Madrasah Aliyah al-Khairaat Kota Gorontalo ${ }^{4}$

Madrasah Aliyah al-Khairaat Kota Gorontalo didirikan pada tanggal 1 Januari 1980. Madrasah Aliyah al-Khairaat merupakan salah satu madrasah berstatus swasta yang terletak di kelurahan Dembe II Kecamatan Kota Timur Kota Gorontalo. Eksistensi Madrasah Aliyah al-Khairaat telah banyak memberikan kontribusi bagi pengembangan sumber daya manusia (SDM) pada Provinsi Gorontalo bahkan sampai luar daerah seperti Kabupaten Bolaang Mongondow Utara, Kabupaten Bolaang Monggondow Selatan dan Daerah lainnya di Jazirah Sulawesi.

Dengan masih berstatus swasta, Madrasah Aliyah alKhairaat Kota Gorontalo masih banyak mengalami berbagai kendala-kendala yang dihadapi. Seperti yang di hadapi oleh madrasah-madrasah lainnya yang ada di Provinsi Gorontalo dan Kota Gorontalo pada khususnya. Sarana prasarana merupakan kendala yang kerap dirasakan dan sampai saat ini merupakan kendala dalam menjalankan proses pembelajaran di Madrasah Aliyah al-Khairaat tersebut.

Dengan predikat Akreditas B oleh BAP S/M Gorontalo SK Nomor: 184.4/BAP-S/M-Gtlo/2007. Tanggal 14 Desember 2007, MA al-Khairaat selalu berbenah untuk memperbaiki kualitas dan mutu pendidikan. Layaknya seperti institusi lain Madrasah Aliyah al-Khairaat telah banyak mengalami pergantian kepemimpinan seiring dengan berputarnya roda zaman. Tercatat telah empat kali terjadi pergantian kepemimpinan di madrasah ini sejak tahun 1980 sampai sekarang. Mereka yang pernah memimpin masing-masing $\mathrm{H}$. Abdul Muin Mooduto (1980-1986), Saud B. Dunggu BA (1986-1992), Drs. Hairin Imran, M.Pd (1992-2003), Drs. Mahfuddin, M.Pd, (2003sekarang).

Madrasah Aliyah al-Khairaat Kota Gorontalo memiliki sumber daya manusia yang cukup untuk menyelenggarakan pendidikan. Dewasa ini, tenaga pengajarnya berjumlah 34 orang, 21 orang telah berstatus pegawai negeri sipil dengan kualifikasi pendidikan; 3 orang magister (S2), 15 orang sarjana (S1) perguruan tinggi Islam, 10 orang sarjana (S1) dari perguruan tinggi umum, dan tinggal satu orang guru yang

${ }^{4}$ Data dan informasi didapat dari Profil MA al-Khairaat 2010. 
berpendidikan Diploma tiga (D3) serta tidak ada guru yang berpendidikan di bawah Diploma.

Selain guru PNS, juga terdapat guru honorer atau non-PNS, berdasarkan tabel di atas dapat dipahami bahwa guru non-PNS yang turut membantu penyelenggaraan pendidikan di Madrasah Aliyah al-Khairaat Kota Gorontalo juga memiliki kualifikasi pendidikan yang memuaskan. Terdapat tujuh orang berpendidikan strata satu (S1) dan dua orang lainnya dengan kualifikasi pendidikan setingkat SLTA.

Keberadaan tenaga honorer sebagaimana pengamatan, juga membantu penyelenggaraan pendidikan dalam hal administrasi sekolah. Keadaan guru non-PNS dimaksud terasa cukup membantu penyelenggaraan pendidikan di Madrasah Aliyah alKhairaat Kota Gorontalo, sebab merekalah yang kemudian dengan penuh keseriusan membantu tugas guru PNS untuk melangsungkan pembelajaran terhadap 495 siswa Madrasah Aliyah al-Khairaat yang tersebar pada 3 tingkatan kelas dan 3 jurusan. Bagi Madrasah Aliyah al-Khairaat Kota Gorontalo, 407 siswa sudah cukup dan memadai. Hal ini mengingat persaingan perekrutan siswa baru pada setiap lembaga pendidikan cukup tinggi, bahwasanya lembaga pendidikan yang berorientasi pada bidang keagamaan menunjukkan penurunan minat bagi calon siswa dan cenderung memilih lembaga-lembaga pendidikan yang berstatus negeri, artinya lembaga pendidikan yang berstatus negeri lebih dominan dibandingkan dengan lembaga pendidikan yang berstatus swasta dalam hal perekrutan siswa baru.

Selain komponen guru dan kepala madrasah, sarana dan prasarana juga bagian yang tidak terpisahkan dari setiap penyelenggaraan kegiatan pendidikan. Keberadaan sarana sebagai tempat penyelenggaraan pendidikan dan prasarana sebagai penunjang bagi terlaksana proses pembelajaran secara efektif, dinamis sesuai dengan tujuan yang ditetapkan memiliki peranan penting bagi keberadaan suatu lembaga pendidikan.

Berdasarkan data tentang inventarisir sarana dan prasarana, secara kuantitas maupun kualitas kondisi sarana dan prasarana di Madrasah Aliyah al-Khairaat masih perlu ditingkatkan. Namun dari segi sarana penunjang pembelajaran seperti halnya laboratorium Madrasah Aliyah al-Khairaat sudah dapat dikatakan memenuhi standar kelayakan dalam pembelajaran. 
Jumlah siswa yang terdaftar di MA al-Khairaat tahun ajaran 2010-2011 sebanyak135siswa yang tersebar pada 3 tingkatan kelas yaitu kelas X, XI dan XII, siswa yang berasal dari SMP sebanyak 49 orang, siswa yang berasal dari MTs sebanyak 86 orang. Sementara itu, siswa yang berasal dari Kota Gorontalo sebanyak 68 orang, dari luar kota (kabupaten yang ada di provinsi Gorontalo) sebanyak 38 siswa, dan siswa yang berasal dari luar daerah sebanyak 29 orang $^{5}$. Dilihat dari latar belakang pekerjaan orang tua, sebagian besar siswa berasal dari kelas menengah ke bawah. Terdapat 66 siswa dengan pekerjaan orang tua sebagai petani, 5 di antaranya sebagai buruh tani, 4 orang nelayan, 27 orang pedagang kecil, 22 pegawai negeri sipil baik sebagai guru, pegawai administrasi dan TNI/Polri, selebihnya adalah sebagai tukang kayu, tukang jahit, sopir angkot, tukang bentor dan tidak memiliki pekerjaan tetap. Hanya 1 siswa yang tercatat sebagai anak pengusaha. Data ini menunjukkan bahwa sebagian besar siswa berasal dari keluarga tidak mampu.

3. Madrasah Aliyah al-Huda Kota Gorontalo

Pada tahun 1961 dibentuk Yayasan Amal al-Huda oleh H. Abdullah Djibran berdasarkan Akte Notaris No. 15 Tanggal 19 Juni 1961. Dalam akte ini ditegaskan bahwa yayasan al-Huda bertujuan untuk pendidikan dan dakwah Islamiyah. Pendirian yayasan ini didukung oleh ormas-ormas Islam yang ada di Gorontalo pada saat itu seperti Nahdlatul Ulama, Muhammadiyah, PSII dan ormas-ormas lainnya. ${ }^{6}$

Pada tahun 1995 dilakukan pembenahan Anggaran Dasar Yayasan al-Huda berdasarkan akte Notaris J. Nento tanggal 27 September 1995. Dalam akte ini disebutkan bahwa Yayasan alHuda bertujuan untuk:

a) Mengusahakan pendirian sekolah-sekolah, madrasah-madrasah, pondok pesantren, rumah-rumah yatim piatu dan fakir miskin, dan lain sebagainya.

${ }^{5}$ Diolah dari dokumen data siswa MA al-Khairaat Kota Gorontalo tahun ajaran 2010-2011.

${ }^{6}$ Data dan informasi sebagian besar dikutip dari Profil MA al-Huda 2010, hlm. 2. 
b) Memperhatikan dengan sungguh-sungguh pendidikan/pengajaran agama Islam, serta menggiatkan dakwah/pengajian-pengajian, kursus-kursus, bahkan memperluas ilmu pengetahuan umum juga penyiaran buku-buku, majalahmajalah dan lain sebagainya.

c) Berusaha mempertinggi nilai penyempurnaan akhlak, budi pekerti/kesopanan umat manusia serta membangkitkan minat beramal khair, menghidupkan rasa beragama menuju masyarakat yang sejahtera, adil dan makmur.

d) Bersedia bekerja sama dengan yayasan lainnya, sekolahsekolah, atau Pondok pesantren dari berbagai tingkatan dengan tujuan yang sama.

Berdasarkan tujuan inilah maka Yayasan Al-Huda menyelenggarakan beberapa kegiatan pendidikan yaitu:

a) Pendidikan jalur sekolah meliputi: Taman Kanak-kanak Al-Huda, sekolah dasar berbantuan (SDB) Al-Huda, Madrasah Ibtidaiyah Diniyah, Madrasah Tsanawiyah, Madrasah Aliyah.

b) Pendidikan jalur luar sekolah meliputi: bidang kajian kitab kuning, tahfizz al-Qur'ān, pelajaran Bahasa Arab dan Bahasa Inggris. ${ }^{7}$

Semua unit lembaga pendidikan di atas inilah yang masih eksis hingga kini dan ikut menunjang eksistensi pondok pesantren Al-Huda sebagai salah satu lembaga pendidikan Islam di Gorontalo. Madrasah Aliyah Al-Huda yang didirikan pada tahun $1961,{ }^{8}$ hingga saat ini masih berstatus "terdaftar". Madrasah ini bernaung di bawah yayasan pendidikan dan dakwah Islamiyah Al-Huda saat ini membina sebanyak 398 santri/santriwati.

Untuk menunjang kegiatan belajar mengajar di MA AlHuda, maka madrasah ini memiliki 38 orang tenaga kependidikan berupa guru/ustadz yang berasal dari tiga institusi yakni kementerian agama, kemeterian pendidikan nasional, dan berasal dari yayasan pendidikan dan dakwah Islamiyah AlHuda, yang sebagian besar di antaranya sudah berstatus PNS

${ }^{7}$ Selengkapnya lihat Akte Notaris J. Nento, SH Tentang Perubahan Anggaran Dasar Yayasan al-Huda Tanggal 27 September 1995, hlm.35.

${ }^{8}$ Didasarkan pada Piagam Pendirian Madrasah Swasta yang dikeluarkan oleh Kanwil Depag Provinsi Sulawesi Utara tanggal 4 Januari 1993. 
dan berkualifikasi pendidikan S1 dan S2 dengan rincian, guru kementerian agama 8 orang, guru kementerian pendidikan nasional 15 orang dan guru yayasan 15 orang.

Dari aspek kurikulum pembelajaran, struktur kurikulum MA Al-Huda disusun dengan memperhatikan tuntutan visi, misi, dan tujuan MA Al-Huda yang disesuaikan dengan kondisi madrasah dan pondok pesantren, karakter sumber daya manusia yang dimiliki, serta keinginan orang tua sebagai user pendidikan. Pendidikan agama; Al-Quran dan Hadis, Aqidah Akhlak, Fiqih kemenag, SKI, pendidikan pesantren; al-Qur'ān Tajwìd, Tauhìd, Qawāid, Ḥadìs, Imla', Mahfüzāt, Muhādaśah, Fiqh Pondok, Pendidikan Kewarganegaraan, Bahasa Indonesia, Bahasa Inggris, Bahasa Arab, Matematika, IPA, IPS, Seni Budaya, Pendidikan Jasmani, Olah Raga dan Kesehatan. ${ }^{9}$

Struktur Kurikulum MA al-Huda sebagaimana telah dipaparkan di atas telah menggabungkan berbagai mata pelajaran baik itu untuk tujuan pembinaan keterampilan (life skill) maupun untuk pembinaan mentalitas dan kepribadian anak didik, yang sangat bermanfaat sebagai bekal hidup mereka dalam bermasyarakat.

Keadaan siswa di Madrasah Aliyah al-Huda tercatat sebanyak 176 siswa tersebar di 3 tingkatan; kelas X 61 siswa, kelas XI 58 siswa dan kelas XII 57 siswa. Dilihat dari asal daerah, sebagian besar adalah berasal dari kota Gorontalo, yaitu sebanyak 100 siswa, sementara dari luar kota Gorontalo sebanyak 52 siswa dan 24 siswa berasal dari luar daerah (Sulawesi Utara dan Tengah). Meskipun sebagian besar berasal dari kota Gorontalo, tetapi jika ditelusuri latar belakang ekonomi, sebagian besar adalah masyarakat kelas bawah. Hal ini dapat dilihat dari profesi orang tua siswa; petani 53 orang, pedagang 66 orang, tukang bentor 2 orang, pensiunan 3 orang, montir 1 orang, tukang kayu 3 orang, wirausaha kecil 28 orang dan pegawai negeri sipil (guru, tenaga administrasi, polisi 20 orang.

Berdasarkan data tersebut dapat dikatakan bahwa hampir seluruh siswa Madrasah Aliyah Al-Huda berasal dari masyarakat kelas menengah ke bawah.

${ }^{9}$ Dikutip dari Dokumen Kurikulum MA al-Huda Gorontalo 2008-2010. 
4. Madrasah Aliyah Muhammadiyah Kota Gorontalo ${ }^{10}$

Awal mulanya Madrasah Aliyah Muhammadiyah adalah PGAP (Pendidikan Guru Agama Pertama) didirikan pada tahun 1951 dengan lama pendidikan 4 tahun dan beroperasi selama 6 tahun dari tahun $1951 \mathrm{~s} / \mathrm{d}$ 1957. Setelah tahun 1957 PGAP berubah status menjadi PGAA (Pendidikan Guru Agama Atas) dengan lama pendidikan 2 tahun dan beroperasi dari tahun 1957 s/d 1963, dengan Peraturan Menteri Agama tahun 1963 PGAP dan PGAA digabung menjadi PGA dengan lama pendidikan 6 tahun. Akan tetapi pada tahun 1979 beralih status menjadi Madrasah Aliyah Muhammadiyah. ${ }^{11}$

Sejalan dengan hal itu pula Madrasah Aliyah Muhammadiyah Kota Gorontalo terus berkembang sampai dengan saat ini dengan adanya penambahan gedung dan sarana prasarana yang menunjang dalam proses kegiatan belajar mengajar. Apabila dilihat dari letak segi geografis Madrasah Aliyah Muhammadiyah letaknya sangat strategis dan bisa dijangkau oleh seluruh sarana alat transportasi darat yang jaraknya tepat di pusat Kota. Madrasah Aliyah Muhammadiyah berlokasi di jalan Dr. Aloei Saboei Kelurahan Limba U Kec. Kota Selatan. Hal ini dapat dilihat dari segi geografisnya yaitu: Sebelah utara berbatasan dengan Jl. Gelatik, sebelah timur berbatasan dengan Jl. Kasuari, sebelah selatan berbatasan dengan Tjokroaminoto dan sebelah barat berbatasan dengan Jl. Panjaitan (Bundaran Hulonthalo Indah Pertamina).

Dalam hal kepemimpinan, menjadi sebuah keniscayaan sebagai konsekuensi logis dari perputaran waktu bahwa dinamika menuntut adanya perubahan-perubahan periodisasi. Demikian halnya pada Madrasah Aliyah Muhamadiyah Kota Gorontalo, telah terjadi 11 kali pergantian kepemimpinan kepala madrasah masing-masing: Madina Abdullah (1951-1959), Ari Monoarfa (1960-1961), Abas Mahmud, (1961-1962), AR. Hioda (19631964), Ahmad Madun Gani (1964-1965), Umi Walangadi (1965-1966), Abd. Rahman Mahmud (1967-1969), AR. Hioda, (1970-1975), Marwan Hioda, BA, (1976-1997), Hasna Domili, BA, (1998-2006), Romy Bau, S.Ag, M.Si (2007- sekarang).

\footnotetext{
${ }^{10}$ Data dan informasi diperoleh dari Profil MA Muhammadiyah 2010.

${ }^{11}$ Romy Bau, Kepala Madrasah Aliyah Muhammadiyah Gorontalo, "Wawancara”, tanggal 11 Februari 2011.
} 
Sebagai lembaga pendidikan Islam, maka Madrasah Aliyah Muhammadiyah Gorontalo menekankan pendidikan berbasis Agama. Dengan demikian bobotan pelajaran keagamaan menjadi prioritas. Hal tersebut tampak dari pembagian kurikulum mata pelajarannya yakni $70 \%$ untuk mata pelajaran agama dan $30 \%$ untuk mata pelajaran umum.

Guru sebagai tenaga pengajar dalam kegiatan belajar mengajar di madrasah harus mempunyai kualifikasi khusus dan pengetahuan yang memadai dalam proses mentransfer ilmu pengetahuan kepada siswanya. Guru di Madrasah Aliyah Muhammadiyah Gorontalo berjumlah 15 orang, guru tidak tetap berjumlah 9 orang, pegawai tata usaha berjumlah 2 orang, sedangkan satpam 1 orang dari data tersebut guru yang ada sudah memenuhi target.

Dengan demikian, rasio antara guru dan siswa kurang lebih satu berbanding empat (1:4). Satu orang guru menangani 4 orang siswa. Dengan sendirinya dapat dipahami bahwa rasio yang ada menunjukkan kurangnya siswa pada satu sisi serta jumlah guru yang relatif tinggi pada sisi lainnya.

Keadaan siswa di Madrasah Aliyah Muhammadiyah Gorontalo secara keseluruhan berjumlah 93 orang yang tersebar pada 3 tingkatan kelas dan 2 jurusan masing-masing; siswa kelas X-A berjumlah 20 orang dengan rincian laki-laki 11 orang dan perembuan 14 orang, kelas X-B berjumlah 20 orang dengan rincian laki-laki 9 orang dan perempuan 16 orang, XI IPA berjumlah 17 dengan rincian laki-laki 4 orang dan perempuan 13 orang, XI IPS berjumlah 25 orang dengan rincian 12 orang laki-laki dan perempuan 18 orang, XII IPA berjumlah 5 orang dengan rincian laki-laki 1 orang dan perempuan 4 orang, sedangkan XII IPS berjumlah 17 orang dengan rincian laki-laki 4 orang dan perempuan 2 orang. Adapun jumlah keseluruhan siswa yang berada di Madrasah Aliyah Muhammadiyah Kota Gorontalo berjumlah 93 orang dengan rincian laki-laki 39 orang dan perempuan 57 orang. Madrasah ini memiliki fasilitas yang memadai jika dilihat dari keadaan siswa yaitu terdapat 6 ruang teori kelas dan 12 ruang penunjang lainnya.

Sebagian besar siswa berasal dari kota Gorontalo, yaitu sebanyak 86 orang, sementara sisanya 7 orang berasal dari luar kota dan provinsi Gorontalo. Meskipun sebagian besar siswa berasal dari kota Gorontalo, tetapi jika dilihat dari latar 
belakang ekonomi, hampir keseluruhan berasal dari keluarga tidak mampu. Hal ini dapat dibuktikan dengan jenis pekerjaan orang tua siswa sebagai berikut; petani 59 orang, nelayan 6 orang, pedagang kecil 11 orang, buruh kasar 7 orang, sopir angkot 7 orang satpam 1 orang dan hanya 2 orang yang dipandang sebagai kelas menengah yaitu 1 PNS dan 1 pengusaha. Dengan data ini dapat dikatakan bahwa hampir keseluruhan siswa berasal dari strata masyarakat kelas bawah.

5. Madrasah Aliyah al-Yusra Kota Gorontalo ${ }^{12}$

Dalam catatan sejarah pendidikan madrasah yang ada di di daerah Gorontalo awal tahun 1995, sebelum adanya pemisahan antara Provinsi Sulawesi Utara dengan Provinsi Gorontalo, saat itu Yayasan al-Yusra telah mendirikan 2 madrasah yaitu Madrasah Aliyah dan Madrasah Tsanawiyah yang berlabel alYusra sebagai nama sebuah yayasan pendidikan Islam yang ada di Kelurahan Tomulobutao Kota Gorontalo. Secara operasional, Madrasah Aliyah al-Yusra diresmikan pada tanggal 1 Juli 1995 oleh Kepala Kantor Depertemen Agama Kota Gorontalo saat itu Drs. Amir I. Agoan. ${ }^{13}$ Peresmian itu terwujud atas prakarsa dan upaya para pengurus yayasan alYusra.

Pada awal berdirinya Madrasah Aliyah al-Yusra hanya memiliki 1 rombongan belajar, dengan jumlah siswa 13 orang, sedangkan para gurunya baik kepala madrasah maupun staf berasal dari pengurus yayasan serta guru pinjaman dari Madrasah Ibtidaiyah dan Madrasah Tsanawiyah al-Yusra. ${ }^{14}$

Sejalan dengan arus perubahan sebagai imbas pembangunan yang dilaksanakan oleh pemerintah bersama-sama masyarakat, madrasah inipun terus merayapi perkembangan yang hingga kini telah memiliki sarana dan prasarana yang memadai. Sarana pendidikan yang saat ini dimiliki oleh Madrasah Aliyah al-Yusra dipandang lebih lengkap jika dibandingkan dengan keadaan sarana dan prasarana pendidikan sebelumnya.

Jumlah keseluruhan guru yang bertugas di MA al-Yusra saat ini adalah, 14 orang dengan rincian 2 orang guru pria dan

\footnotetext{
${ }^{12}$ Data dan informasi diperoleh dari Profil MA Al-Yusra 2010.

${ }^{13}$ Madrasah Ibtidaiyah Al-Yusra, Masalah yang Mendasari Berdirinya MIS Al-Yusra Tahun 1995, hlm. 2.

${ }^{14}$ Profil Madrasah Aliyah Al-Yusra Kota Gorontalo, Tahun 2011.
} 
12 orang guru wanita termasuk kepala madrasah. Dari status kepegawaian 10 orang NIP 15 dengan unit kerja Departemen Agama, 1 orang NIP 13 dengan unit kerja Diknas. Sedangkan untuk guru tidak tetap/honorer sebanyak 3 orang. Sedangkan dari kualifikasi pendidikan, hanya 4 orang bergelar sarjana (S1), dan sisanya bergelar Diploma (D2).

Fasilitas ruangan masih sangat minim, tetapi setara dengan jumlah siswa yang hanya 38 orang yaitu 4 buah ruangan kelas dan 5 ruangan penunjang lainnya. Secara fisik MA al-Yusra menunjukkan peningkatan yang baik jika dibandingkan pada awal berdirinya, di mana pada awal berdirinya hanya memiliki 1 ruang kelas, sekarang telah memiliki 4 ruang kelas yang digunakan untuk 6 rombongan belajar, 1 ruang kepala madrasah, 1 ruang dewan guru, 1 ruang UKS, 1 buah masjid, 2 buah komputer dan 1 buah kamar mandi/WC.

Berdasarkan data yang telah diuraikan di atas, maka dapat disimpulkan bahwa kondisi Madrasah Aliyah al-Yusra Kota Gorontalo saat ini telah menunjukkan peningkatan yang signifikan baik dari segi manajemen kepemimpinannya, rasio jumlah guru dan siswa seimbang, serta fasilitas pendukung penyelenggaraan pendidikan cukup tersedia. Hal ini sudah barang tentu memberi motivasi kepada pihak madrasah untuk selalu berinovasi guna menunjukkan jati diri madrasah yang mampu bersaing di bidang prestasi dan kualitas mutu penyelenggaraan pendidikan.

Jumlah siswa yang memilih bersekolah di Madrasah Aliyah al-Yusra sebanyak 80 siswa; kelas X 28 siswa, kelas XI 23 siswa dan kelas XII 29 siswa. Tidak semua siswa berasal dari kota Gorontalo, yaitu hanya 25 siswa yang berasal dari sekitar madrasah, sementara 48 siswa berasal dari luar kota Gorontalo dan 7 siswa berasal dari Sulawesi Utara dan Ternate. Sebagai sebuah madrasah yang berada di pinggiran kota Gorontalo. Hampir keseluruhan siswa berasal dari keluarga tidak mampu atau strata sosial kelas bawah. Fakta ini dapat ditunjukkan dengan jenis pekerjaan orang tua siswa sebagai berikut; petani 50 orang, nelayan 4 orang, wiraswasta 12 orang, buruh kasar 7 orang, pedagang kecil 3 orang, tukang kayu 2 orang dan pegawai honorer 2 orang. 
6. Madrasah Aliyah Nurul Yaqin Kota Gorontalo ${ }^{15}$

Madrasah Aliyah Nurul Yaqin adalah Madrasah Aliyah termuda di kota Gorontalo, didirikan tahun 2005, pembangunannya tidak bisa dipisahkan dari keberadaan Madrasah Tsanawiyah Nurul Yaqin yaitu sebagai upaya menampung lulusan Madrasah Tsanawiyah. Madrasah ini diprakarsai oleh Drs. Anas S. Mahmud yang saat itu menjabat sebagai kepala Madrasah Tsanawiyah Nurul Yaqin. Pada tahun 2006, Madrasah Aliyah Nurul Yaqin diresmikan oleh Kepala Departemen Agama Provinsi Gorontalo Bapak Moh. Salim Al Djufri dengan ditandai oleh peletakan batu pertama gedung Madrasah Aliyah Nurul Yaqin yang terletak bersebelahan dengan Madrasah Tsanawiyah Nurul Yaqin.

Awal berdirinya madrasah ini masih menempati salah satu ruang kelas Madrasah Tsanawiyah Nurul Yaqin dengan jumlah siswa 11 orang dengan rincian 10 orang laki-laki dan 1 orang perempuan, keseluruhan siswa tersebut berasal dari Madrasah Tsanawiyah Nurul Yaqin. Pada tahun ajaran 2007-2008 jumlah siswa mengalami peningkatan yaitu 31 orang, tahun 2008-2009 berjumlah 43 orang, tahun 2009-2010 berjumlah 53 orang dan tahun 2010-2011 berjumlah 66 orang.

Saat ini jumlah tenaga pengajar di Madrasah Aliyah Nurul Yaqin berjumlah 17 orang masing-masing 7 orang guru lakilaki dan 10 orang guru perempuan. Status tenaga pengajar adalah 7 orang PNS dan 10 orang non-PNS. Dari segi tingkat pendidikan yakni 11 orang berpendidikan S1, 1 orang D2, dan sisanya 5 orang lulusan Madrasah Aliyah yang saat ini sedang menempuh pendidikan S1 baik di IAIN Sultan Amai Gorontalo maupun di Universitas Negeri Gorontalo.

Selanjutnya dari segi fisik, Madrasah Aliyah Nurul Yaqin memiliki 3 ruang belajar (kelas), dan 1 ruang digunakan untuk kepala madrasah, guru dan tata usaha. Di dalam area Madrasah Aliyah Nurul Yaqin juga terdapat laboratorium tapi merupakan milik Madrasah Tsanawiyah yang kebetulan tidak memiliki area tanah untuk pembangunan gedung tersebut. Gedung laboratorium ini juga digunakan oleh siswa dan guru Madrasah

${ }^{15}$ Data dan informasi didapat dari Profil MA Nurul Yaqiin Kota Gorontalo. 
Aliyah Nurul Yaqin untuk melaksanakan salat berjamaah karena belum terisi perangkat laboratorium.

Sebagai sebuah lembaga pendidikan yang baru "seumur jagung", keberadaan Madrasah Aliyah Nurul Yaqin masih perlu mendapatkan perhatian semua pihak, baik pemerintah maupun masyarakat. Karena dari kondisi sarana dan prasarana yang telah digambarkan tersebut terlihat masih sangat minim dan belum ideal bagi penyelenggaraan pendidikan dan pengajaran setingkat Madrasah Aliyah.

Madrasah ini tercatat sebagai madrasah yang paling sedikit jumlah peminatnya. Hal ini dapat diakui karena umur pendiriannya yang belum terlalu lama. Sebagai madrasah yang baru berdiri dan berada di pinggiran kota Gorontalo bagian utara, maka siswa yang meminati madrasah ini berasal dari wilayah sekitar madrasah ditambah dengan siswa yang berasal dari luar kota dengan rincian; kota Gorontalo 43 orang, luar Kota Gorontalo sebanyak 23 orang. Belum ada siswa yang berasal dari luar provinsi. Sebagaimana latar belakang ekonomi orang tua pada Madrasah Aliyah yang lain, tidak jauh berbeda dengan kondisi ekonomi orang tua siswa di madrasah ini, yaitu 37 orang petani, 12 orang pedagang, 6 orang wirausaha dan 10 orang pengrajin, tukang kayu dan tukang bentor.

Untuk melihat lebih jelas perkembangan siswa Madrasah Aliyah dari tahun ke tahun dalam kurun waktu 5 tahun terakhir dapat dilihat pada tabel berikut ini;

\section{Tabel 1}

Perkembangan Siswa Madrasah Aliyah Se Kota Gorontalo Tahun 2006-2011

\begin{tabular}{llccccc}
\hline \multirow{2}{*}{ No } & \multirow{2}{*}{ Nama Madrasah } & \multicolumn{5}{c}{ Tahun Ajaran } \\
\cline { 3 - 7 } & & $2006 /$ & $2007 /$ & $2008 /$ & $2009 /$ & $2010 /$ \\
& & 2007 & 2008 & 2009 & 2010 & 2011 \\
\hline 1 & MAN Model Gorontalo & 105 & 121 & 186 & 143 & 202 \\
\hline 2 & MA. Al-Khairaat & 21 & 28 & 35 & 47 & 54 \\
\hline 3 & MA. Al-Huda & 47 & 51 & 57 & 58 & 61 \\
\hline 4 & MA. Muhammadiyah & 19 & 29 & 22 & 42 & 40 \\
\hline 5 & MA. Al-Yusra & 12 & 17 & 29 & 23 & 28 \\
\hline 6 & MA.Nurul Yaqin & - & 11 & 31 & 43 & 53 \\
\hline & Jumlah Total & 204 & 257 & 342 & 356 & 438 \\
\hline
\end{tabular}

Sumber: Kementerian Agama Prov. Gorontalo 
Tabel 1 menunjukkan perkembangan jumlah siswa yang masuk ke Madrasah Aliyah setiap tahun ajaran baru. Data ini pun dapat menunjukkan minat masyarakat terhadap Madrasah Aliyah di Gorontalo. Jika direkapitulasi, perkembangan tersebut adalah; pada tahun ajaran 2006/2007, secara keseluruhan siswa yang mendaftar di Madrasah Aliyah se-Kota Gorontalo adalah sebanyak 204 siswa, pada tahun ini belum termasuk Madrasah Aliyah Nurul Yaqiin karena madrasah ini belum dibuka.

Pada tahun ajaran 2007/2008, jumlah siswa yang mendaftar di Madrasah Aliyah se-Kota Gorontalo adalah sebanyak 257 siswa. Pada tahun ini, Madrasah Aliyah Nurul Yaqiin sudah dibuka dengan jumlah siswa 11 orang, sehingga menambah jumlah siswa Madrasah Aliyah secara keseluruhan.

Pada tahun ajaran 2008/2009, jumlah siswa yang mendaftar pada Madrasah Aliyah se kota Gorontalo sebanyak 342 siswa dengan rincian mendaftar di MAN Model Gorontalo sebanyak 168 siswa, Madrasah Aliyah al-Khairaat 35 siswa, Madrasah Aliyah al-Huda 57 siswa, Madrasah Aliyah Muhammadiyah 22 orang, Madrasah Aliyah al-Yusra 29 siswa dan Madrasah Aliyah Nurul Yaqiin 31 siswa. Kemudian pada tahun ajaran 2009/2010 jumlah siswa yang mendaftar di Madrasah Aliyah se-Kota Gorontalo sebanyak 356 siswa dengan rincian; MAN Model Gorontalo sebanyak 143 siswa, Madrasah Aliyah al-Khairaat 47 siswa, Madrasah Aliyah al-Huda 58 siswa, Madrasah Aliyah Muhammadiyah 42 orang, Madrasah Aliyah al-Yusra 23 siswa dan Madrasah Aliyah Nurul Yaqiin 43 siswa. Dan terakhir pada tahun ajaran 2010/2011, jumlah siswa yang mendaftar di Madrasah Aliyah se-Kota Gorontalo sebanyak 438 siswa dengan rincian: MAN Model Gorontalo sebanyak 202 siswa, Madrasah Aliyah al-Khairaat 54 siswa, Madrasah Aliyah Al-Huda 61 siswa, Madrasah Aliyah Muhammadiyah 40 siswa, Madrasah Aliyah Al-Yusra 28 siswa dan Madrasah Aliyah Nurul Yaqiin 43 siswa.

Dengan demikian, setiap tahun ajaran, terjadi peningkatan siswa yang mendaftar di Madrasah Aliyah se kota Gorontalo yaitu tahun 2006/2007 sebanyak 53 siswa, tahun 2007/2008 meningkat tajam 95 siswa, tahun 2008/2009, meningkat tahun 2009/2010 meningkat hanya 14 siswa dan tahun 2010/2011 meningkat lagi 82 siswa. 
Peningkatan jumlah siswa yang mendaftar di Madrasah Aliyah ini bukan hanya karena terjadinya peningkatan minat masyarakat terhadap Madrasah Aliyah, namun juga terjadi karena seiring pertumbuhan jumlah penduduk yang berimplikasi pada peningkatan jumlah usia sekolah.

\section{Penutup}

Ciri khas pendidikan madrasah dengan kurikulum agama Islam sebagai backround-nya apabila dikelola dan ditata dengan baik akan menjadi salah satu keunggulan pendidikan di Gorontalo. Dalam hal ini penduduk Gorontalo mayoritas penganut agama Islam dan Gorontalo menjadi provinsi ke 32 menjadi modal besar untuk mendirikan Madrasah Aliyah Kejuruan (MAK) dengan model integrasi dan interkoneksitas keilmuan. Apalagi Madrasah Aliyah kejuruan dengan kurikulum berbasis kawasan, sebut saja kejuruan dalam bidang teknologi dan budidaya enceng gondok, rumput laut dan komoditas jagung di mana selama ini Gorontalo dikenal sebagai daerah produsen dan pengekspor jagung terbesar di Indonesia. Sehingga yang dapat dilahirkan dari tulisan ini adalah menghadirkan Madrasah Aliyah kejuruan dengan kurikulum terintegrasi dan terinterkoneksi dalam hal keilmuan dengan menerapkan kurikulum berbasis kawasan dengan tidak melupakan basis keislaman sebagai ciri khas utama Madrasah Aliyah. Model Madrasah Aliyah yang diusulkan dari tulisan ini memiliki 3 keunggulan yaitu keunggulan fisik (hardware), keunggulan non fisik (software) dan keunggulan jaringan (networking).

\section{Kepustakaan}

Abdullah, M. Amin, Islamic Studies di Perguruan Tinggi; Pendekatan Integratif-Interkonektif, (Yogyakarta: Pustaka Pelajar, 2010).

Abu Bakar, Usman \& Surohim, Fungsi Ganda Lembaga Pendidikan Islam, Respon Kreatif Terhadap UndangUndang Sisdiknas (Yogyakarta: Safiria Insani Press, 2005).

Ashraf, Ali, Horison Baru Pendidikan Islam, (Jakarta: Pustaka alHusna, 1993).

Departemen Agama Republik Indonesia, Sejarah Madrasah: Pertumbuhan, Dinamika, dan Perkembangannya di 
Indonesia (Jakarta: Departemen Agama Republik Indonesia, 2004).

Hasbullah, Sejarah Pendidikan Islam di Indonesia, (Jakarta: LSIK dan Raja Grafindo Persada, 1999).

Masyuri AM, dan Taufiq Dahlan (Ed), Profil Madrasah Masa Depan, (Jakarta: MP3A Departemen Agama RI, 2006).

Modanggu, Thariq, Model Pendidikan Islam Dalam Pembentukan Karakter Bangsa, Gorontalo, (Laporan Penelitian: Lemlit IAIN Sultan Amai Gorontalo, 2010).

Mustofa, Ahmad dan Abdullah Ali, Sejarah Pendidikan Islam di Indonesia, (Bandung: Pustaka Setia, 1997).

Polontalo, Ibrahim, Persekolahan Swasta di Gorontalo Serta Pengaruhnya dalam Pengembangan Pendidikan di Daerah Gorontalo, (Gorontalo: IKIP, 1997).

Posangi, Said Subhan, Studi tentang Persepsi Masyarakat terhadap Eksistensi Lembaga Pendidikan Islam, (Tesis: UIN Alauddin Makassar, 2004).

Qomar, Mujamil, Manajemen Pendidikan Islam. (Jakarta: Erlangga, 2007).

Shaleh, Abdul Rachman, et al., Pengembangan Ciri Khas Madrasah, (Jakarta: MP3A Departemen Agama RI., 2006).

Tuloli, Naniedt.all (ed), "Membumikan Islam" Seminar Nasional Pengembangan Kebudayaan Islam Kawasan Timur Indonesia, (Gorontalo: Pusat Penelitian dan Pengkajian, Badan Pengembangan Kebudayaan Islam Kawasan Timur Indonesia di Gorontalo, 2004).

Usman, Masjruljanto, "Gorontalo Kota Madrasah", Makalah Lomba Karya Tulis Ilmiah (Gorontalo, 2010). 
